\title{
Employment Law Update
}

Patricia S. Wall, (Email: patwall@ comcast.net), Middle Tennessee State University

Lara Womack, (Email: lwomack@mtsu.edu), Middle Tennessee State University

\section{INTRODUCTION}

$\mathrm{t}$ is important for managers to keep abreast of developments in employment law. Every year the law is refined as courts are presented and resolve new questions. Many of these are questions of statutory interpretation. Some are issues of common law. This article reviews recent court cases involving the interpretation of important statutes, such as the Civil Rights Act, the Fair Labor Standards Act, and the Age Discrimination Act. It also reviews developments in the common law area of privacy issues (Landesman, 2004).

\section{THE CIVIL RIGHTS ACT}

Forty years after its passage, the Civil Rights Act (CRA) continues to be the source of considerable litigation. One recent case contributes to an understanding of what type of conduct constitutes sexual harassment. Another addresses attempts to balance the prohibition against discrimination on the basis of gender with the need for individual privacy.

In the first case, Ocheltree v. Scollon Production Inc. (2002), the United States Court of Appeals for the $4^{\text {th }}$ Circuit found that sexual comments or behavior that is offensive to both genders cannot be the grounds for a discrimination claim based upon sex. Further, the court reiterated the holding in Hopkins v. Baltimore Gas \& Electric Co. (1996) that "Title VII was not designed to create a federal remedy against offensive language and conduct in the workplace."

This case was initiated by an employee who was discharged for excessive absenteeism, excessive personal use of the telephone during working hours, and after the threatening of her supervisor by her husband. The employee, Ms. Ocheltree, sued Scollon Productions for sexual harassment in violation of Title VII of the CRA, claiming that she had been exposed to lewd jokes, among other things. According to Title VII,

it is an unlawful employment practice for an employer...to fail or refuse to hire or to discharge ..or otherwise discriminate against any individual with respect to his compensation, terms, condition or privileges of employment because of such individual's sex (42 USCA § 2000e-2(a) (1)).

This provision of the act was extended to what is commonly referred to as hostile environment cases in Meritor Savings Bank v. Vinson (1986). In that case it was held that the workplace is one of the "terms, conditions, or privileges of employment," and thus a person forced to work in hostile work environment may sue. The courts in Spicer v. Virginia (1995) and Brown v. Perry (1999) concluded that the following elements were needed to prove sexual harassment based upon a hostile or abusive work environment: "(1) the subject conduct was unwelcome, (2) it was based on the sex of the plaintiff, (3) it was sufficiently severe or persuasive to alter the plaintiff's conditions of employment and to create an abusive work environment, and (4) it was imputable on some factual basis to the employer" (Spicer, 1995).

In Ocheltree, the trial court found for the employee, but the court of appeals reversed and found for Scollon. The court of appeals based its decision on the second and third factors identified above. It determined that Ocheltree's alleged harassment was not because of her sex since she would have been exposed to the same harassment even if she had been male. The court stressed that the behavior in question preceded Ocheltree's employment at Scollon and did not end with her dismissal. Further, the court found that the behavior did not meet the criteria of being "sufficiently severe or pervasive to alter the plaintiff's conditions of employment and to create an abusive working environment." 
Despite the fact that the employer prevailed in this case, it should be noted that it was necessary to pursue the appeal in order to do so. Employers, therefore, should continue to train supervisors that any sexual comments or behaviors in the workplace may subject them to charges of sexual harassment.

Slivka v. Camden-Clark Memorial Hospital (2004), dealt with a different type of discrimination. In this case a male registered nurse sued the hospital that employed him after he had been denied a position in obstetrics. The hospital had a policy of refusing to hire male nurses in obstetrics because of patient privacy concerns. The trial court granted the hospital summary judgment. The Supreme Court of Appeals of West Virginia, reversed and remanded.

Slivka, the male RN, brought his lawsuit against Camden-Clark Memorial Hospital under the Virginia Human Rights Act, alleging that the hospital's long-term policy resulted in gender discrimination. The hospital responded that its policy was necessary because gender was a bona fide occupational qualification (BFOQ) or qualification necessary to perform the job. The court, noting that the analytical framework and structures developed under Ttile VII of the Civil Rights Act of 1964 were applicable to cases brought pursuant to the state law, reviewed the federal law under 42 U.S.C. $\$ 2000 \mathrm{e}-2$ (1991), which states that,

It shall be unlawful for an employer (1) to fail or refuse to hire or to discharge any individual, or otherwise to discriminate against any individual with respect to his compensation, terms, conditions, or privilege of employment, because of such individual's race, color, religion, sex, or national origin... Notwithstanding any other provision of this subchapter, (1) it shall not be an unlawful employment practice for an employer to hire and employ employees. . . on the basis of his religion, sex, or national origin in those certain instances where religion, sex, or national origin is a bona fide occupational qualification reasonably necessary to the normal operation of that particular business or enterprise.

According to the Virginia Human Rights Act, the employer must prove the following elements to demonstrate a bona fide occupational qualification: "(1) how the essence or central mission of the business would be undermined by hiring members of both sexes; (2) the factual basis of the employer's belief that all or substantially all members of one gender could not perform the essential duties of the job in question without intruding on legitimate privacy concerns of its patrons; and (3) why alternatives to the gender-excluding policy would be impossible or impractical to achieve" (West's Ann. W. Va. Code, 5-11-9).

The United States Supreme Court viewed the BFOQ exception very narrowly in Dothard v. Rawlinson (1977), when it adopted a two-part testing upholding as a BFOQ a state penitentiary's policy of excluding females from employment as correctional officers dealing with the general prison population, including violent sex offenders. The two-part test used to determine that gender is a BFOQ was: "(1) the essence or central mission of its business would be undermined by hiring members of both sexes, and (2) there is a factual basis for believing that all or substantially all persons of one gender could not perform the job duties satisfactorily."

While the Slivka court acknowledged that several federal courts, such as Fesel v. Masonic Home of Delaware, Inc.(1978), have addressed privacy issues in BFOQ cases and found that they warrant the BFOQ exception, it has not been addressed by the US Supreme Court although it was not eliminated as possible basis for this in such other cases as International Union, United Automobile, Aerospace and Agricultural Implement Workers of America, UAW v. Johnson Controls, Inc (1991). Furthermore, the Slivka court noted that most federal courts that have dealt with these cases have added a third prong to the Dothard test: "(3) it is not feasible due to the nature of the business operation to assign job responsibilities in a selective manner so as to satisfy both the privacy interests of patients and the equal employment opportunity principle of Title VII." The Slivka court found Backus v. Baptist Medical Center (1982) to be factually similar. In this case, a United States District Court in Arkansas determined that being female was a BFOQ for working on a hospital's labor and delivery staff because of privacy concerns. The Backus court found that it was not possible for the hospital to satisfy both privacy and Title VII interests without creating unmanageable staffing problems. This issue was also addressed in Equal Employment Opportunity Commission v. Mercy Health Center (1982).

After a review of the relevant case law, the Supreme Court of Appeals of West Virginia recognized that privacy concerns might support gender as a BFOQ. It emphasized, however, the need to fully examine the factual basis 
for practices such as those implemented by Camden-Clark. Finding that the record in this particular case was deficient, the Supreme Court reversed the award of summary judgment and remanded the case for further development of the evidence. One omission noted was evidence from patients themselves.

From this, employers should learn that when they are involved in activities that invoke privacy issues, those issues can be balanced against the principle of equal employment. In doing so, however, the employer must take care to fully document the need for its policy.

\section{FAIR LABOR STANDARDS ACT}

The Fair Labor Standards Act (1938) dictates that employees are entitled to overtime compensation if they perform more than forty hours of work in a week. Lunch breaks do not generally count toward those forty hours, but in Beasley v. Hillcrest (2003) employees claimed that their lunch breaks were interrupted so often that the mealtime should be included in that computation.

The plaintiffs in Beasley were nurses or technicians who were allowed a one half hour lunch break during their shift. They claimed that the break was interrupted so often for work purposes that it became time that was spent primarily for the benefit of their employer, and that they should be compensated for it. In the trial court, a summary judgment was awarded to the employer, Hillcrest Medical Center. The judge ruled that the employees had failed to present a triable issue whether their meal periods were spent predominately for the employer's benefit.

On appeal to the United States Court of Appeals for the $10^{\text {th }}$ Circuit, the case was reversed. That court concluded that the employees had raised a triable issue. While this does not mean that the employees won their case, it does mean that they were entitled to a trial on the issue, so the case is instructive as to the type of proof that might take such a case to trial.

The court of appeals referred to federal regulations to identify the appropriate standard for this case. Those regulations state that a bona fide meal period is a rest period during which an employee must be completely relieved from duty for the purposes of eating regular meals. Some interruption of meals would be acceptable, but when the interruption results in the meal periods being spent primarily for the employer's benefit, those meal periods cannot be excluded from compensated time. This results in a "highly individualized and fact based" inquiry.

In this case, one plaintiff testified that she engaged in employment related activities approximately $95 \%$ of the time. Another testified that she never had an uninterrupted meal, and that she never had time to do personal activities during her meal period. A third indicated that her meals were interrupted as much as three or four times per meal and a fourth stated that her pager went off approximately every 10 to 15 minutes. Others testified similarly, and some stated that not only were their activities related to work, but that they were limited in where they took their meal break because of the need to watch patient monitors on a regular basis. The court found that this type of evidence could have supported a finding that the employees spent their meal time predominately for the benefit of the employer.

In addition to contesting the employees' position regarding the use of their mealtime, the employer defended by demonstrating that it had an overtime reporting system, and that managers were not aware that their employees were working uncompensated overtime. The court refused to release the employer from liability on this basis, because the employer was sure to have known that the employees were performing the duties to which they had been assigned. Thus, employers should not rely on the adoption of overtime reporting systems, but should take steps to insure that such policies are fully implemented and being used by employees.

\section{AGE DISCRIMINATION}

The Age Discrimination in Employment Act (ADEA) prohibits employment practices that favor the young over the old. It establishes a threshold of 40 years of age for protection. In 2003, the U.S. Supreme Court addressed the question of whether the act also prohibited practices that favored the older worker over the younger, when the younger was within the 40 years and older category. That case is General Dynamics Land Systems v. Cline (2003). 
In 1997, General Dynamics entered into a collective bargaining agreement that relieved the company of the obligation to provide health care to subsequently retired employees. The agreement, however, exempted those current employees who had reached the age of 50. Thus, it created a group of employees between the ages of 40 and 49 who were protected by the ADEA, but who lost their health coverage upon retirement. That group brought an action against their employer claiming that the agreement violated the ADEA because the benefits were being denied upon the basis of age.

The EEOC agreed that the employees were being treated differently due to their age, and since they were within the protected class created by the ADEA, the agency suggested that the company settle with the employees. The company declined to do so, and lawsuit was filed.

The federal trial court dismissed the case. It relied upon the expressed purpose of the ADEA to address the problem faced by older workers and held that when it was the younger worker who was treated less favorably, the act did not apply, even though the younger worker was over the age of 40.

The aggrieved employees appealed, and the U.S. Court of Appeals for the $6^{\text {th }}$ Circuit reversed the trial court. This court based its decision on the plain language of the act. The ADEA prohibits denying any employee within the protected class an employment benefit solely because of age. The collective bargaining agreement denied a group of employees within the protected class a benefit based upon their age, therefore, the agreement violated the act.

The company then submitted the case to the U.S. Supreme Court, which agreed to hear it. That court examined the act's purpose, history and relationship to other federal statutes and determined that the act was not meant to stop an employer from favoring an older employee over a younger one. In doing so, the Court relied in part on the social history of the ADEA, which established that age discrimination is aimed against the old. It also stated that the position of the EEOC in this matter was clearly wrong.

Three justices, Scalia, Thomas and Kennedy dissented from this opinion. They would have placed greater reliance on the position of the EEOC and less on the social history of the act.

This case illustrates a key distinction between the Civil Rights Act and the Age Discrimination in Employment Act. The CRA prohibits practices on the basis of race, sex, color, religion and national origin without further defining the protected classes. The CRA does not define its protected class as only those of a certain race, or gender. While the ADEA prohibits discrimination on the basis of age, it defines a protected class which includes only those over a certain age. It has always been clear that those under the age of 40 did not enjoy the protection of the act. It is now clear that the protection of the act is extended based upon the employees' relative age; even within the protected class an employee is not protected from practices that favor the older worker. As the Court stated, "[ $[\mathrm{t}] \mathrm{he}$ enemy of 40 is 30 , not 50 ."

Another important point about this case is the manner in which the Court disposed of the EEOC position. Even though the agency charged with enforcing the ADEA had an interpretive regulation supporting the position of the employees, the Court ruled in favor of the employers. All parties should be mindful of the possibility of similar rulings when relying upon agency promulgations.

\section{EMPLOYEE PRIVACY}

Employee privacy issues continue to be impacted by technological developments. As technology advances and becomes more accessible, there will continue to be claims that it is being used to the detriment of some individuals. Several of these claims have arisen in the employment setting.

Many of these cases involve employees suing their employer for invasion of privacy when they discover that their email accounts have been monitored. In Intel Corporation v. Hamdi (2003), however, the company was the party who initiated the lawsuit. Intel claimed that a former employee had misused its email system, and asked that he 
be enjoined from sending email messages into that system. Although a trial court and an appellate court agreed with Intel, those decisions were reversed by the Supreme Court of California.

The email messages in this case were sent by a Mr. Hamidi, a former Intel engineer who had helped form an organization called FACE-Intel. The purpose of the organization was to disseminate information and views were critical of Intel's employment practices. The organization maintained a Web site that contained information about Intel, and Mr. Hamidi sent six mass emails over a 21 months period to employee addresses on Intel's electronic mail system referring them to that Web site. According to the Web site, the emails were sent to as many as 35,000 employees.

Intel sued Mr. Hamidi claiming that his actions constituted a trespass to their personal property, the computer system. It is noteworthy that the company chose this course of action, rather than bringing a lawsuit based upon the content of the messages. There were no claims that the messages were defamatory, or that the result of the content was to unreasonably interfere with contracts between the company and its employees, or on any other feature of the content. The action was limited to the act of sending the messages.

Under the California law of trespass, which is not unique, a plaintiff must prove that the defendant's actions caused an injury to the personal property in order to prevail in trespass (West's Ann. Cal. C.C.P.. $\S ~ 1021.9)$ The injury in such a case, where the personal property intruded upon is a computer system, might be interference with the ordinary operation of the system, a breach of the system's security measures, being dispossessed of computer for some period of time or otherwise being prevented from using the system, or even evidence that the email messages caused the system to work slower. But there was no proof of that type of injury in this case. The only injury identified was the disruption or distraction that resulted from the content of the messages. Because there was no link between the act complained of, sending the messages, and the injury complained of the California Supreme Court denied relief.

The court in Intel had an opportunity to expand the law applicable to technology issues, but chose not to do so. Although the California law of trespass to personal property requires that an injury to the property be demonstrated, a different standard applies to trespass to real property. Some urged the court to use this case as a means of applying real property standards to cases involving interactive Web sites and servers. The court first noted disagreement with the outcome that might result from such an application, but also declined to create an exception for cases involving "cyberspace."

This case demonstrates the difficulty of applying existing common law principles to issues presented by technological advancements, and may offer support for those who argue that a new set of rules will have to be developed to deal with an area that does not fit neatly into either the category of real property or personal property.

\section{CONCLUSION}

Every year courts resolve legal issues that relate to employment relationships. These involve a myriad of statutes and common law principles. It is incumbent upon those charged with making key decisions to monitor such developments in order to avoid litigation when possible, or be prepared for it when it is unavoidable. Employers should document files and provide information concerning separations to the unemployment office in a timely manner.

\section{REFERENCES}

1. Backus v. Baptist Medical Center, 671 F. 2d 1100 (1982).

2. $\quad$ Beasley v. Hillcrest, 78 Fed. Appx. 67 (2003).

3. Brown v. Perry, 184 F. 3 d 388 ( $4^{\text {th }}$ Cir. 1999).

4. $\quad$ Dothard v. Rawlinson, 433 U.S 321, 97 S.Ct. 2720, 53 L. Ed.2d 786 (1977).

5. Equal Employment Opportunity Commission v. Mercy Health Center, 1982 WL 3108 (W.D. Okla.1982).

6. $\quad$ Fesel v. Masonic Home of Delaware, Inc., 447 F.Supp, 1346, (D.Del. 1978).

7. General Dynamics Land Systems v. Cline, 155 L. Ed. 2d 664, 71 USLW 3665, (2003).

8. Hopkins v. Baltimore Gas \& Electric Co., 77 F. 3d 745 ( $4^{\text {th }}$ Cir.1996). 
9. Intel Corporation v. Hamdi, 71 P. 3d 296 (2003).

10. International Union, United Automobile, Aerospace and Agricultural Implement Workers of America, UAW v. Johnson Controls, Inc., 499 U.S. 187, 111 S. Ct. 1196, 113 L. Ed. 2d 158 (1991).

11. Landesman, J. (2004). You and the Law.

12. Meritor Savings Bank v. Vinson, 477 US 57, 64-67, 106 S. Ct. 2399, 91 L. Ed 2d 49 (1986).

13. Ocheltree v. Scollon Production Inc., 308 F. 3d 351, (2002)

14. Slivka a v. Camden-Clark Memorial Hospital, ---S.E. 2d----, 93 Fair Employment practice Case (BNA) 471 (2004).

15. Spicer v. Virginia , 66 F. $3 d 705$ ( $4^{\text {th }}$ Cir. 1995).

16. 29 U.S.C. $\$ 621-634$, (1967).

17. 29 U.S.C. $\$ 201-260$ (1938).

18. 42 U.S.C. $\$ 2000 \mathrm{e}-2000 \mathrm{e}-17$, (1964).

19. West's Ann. Cal. C.C.P. $\S 1021.9$.

20. West's Ann. W. Va. Code, 5-11-9. 